\title{
Resenha - Uma janela de possibilidades na educação da infância em tempos de pandemia. Campinas/SP: Pontes Editores, 2020.
}

\author{
Ana Araujo Costa \\ Mestre em Psicologia Educacional, Universidade Nove de Julho - UNINOVE \\ São Paulo, SP - Brasil \\ anisbanis@gmail.com \\ Rosemary Roggero \\ Doutora em Educação, Universidade Nove de Julho - UNINOVE \\ São Paulo, SP - Brasil \\ roseroggero@uol.com.br
}

Para citar- (ABNT NBR 6023:2018)

COSTA, Ana Araujo; ROGGERO, Rosemary. Resenha. Eccos - Revista Cientifica, São Paulo, n. 58, p. 1-4, e20362, jul./set., 2021. Resenha - Uma janela de possibilidades na educação da infância em tempos de pandemia. Campinas/SP: Pontes Editores, 2020. Disponível em:

https://doi.org/10.5585/eccos.n58.20362.

O livro "Uma janela de possibilidades na educação da infância em tempos de pandemia" é fruto de discussões do grupo de pesquisa Políticas Públicas da Infância, Criando - Pontifícia Universidade Católica (PUC-SP) em parceria com Formep - PUC/SP, perante as inquietações advindas do período de pandemia por Covid-19, que potencializou intensas reflexões originando a supracitada obra.

Assim, essa produção, em formato de manifesto, busca responder perguntas basilares de forma crítica, mediante o período imposto de distanciamento social, quais sejam: "Dessa maneira, quais as contribuições dos estudos que realizamos sobre infância para este contexto de pandemia? Qual nosso papel enquanto pesquisadoras da infância em relação à vida das crianças, diante da consciência que se tem dos seus direitos? E como educadoras, qual a nossa contribuição?" (p. 11).

Nessa confluência, o objetivo do livro versa em refletir e buscar "alternativas para enfrentar, coletiva e colaborativamente, o desafio da construção de políticas públicas para a infância”. (p. 11). A metodologia utilizada é a reflexão dialógica, que se transformou em lives públicas, reuniões virtuais e roda de conversa com outros grupos de pesquisa sobre a infância, que se materializou em manifesto coletivo. Os aportes teóricos utilizados, para as reflexões apresentadas, fundamentam-se nos pensamentos de Paulo Freire e a trama é tecida com uma 
gama de contribuições teóricas a partir dos estudos e pesquisas de cada pesquisadora participante.

Algumas literaturas seminais verticalizaram as discussões iniciais nos seminários propositivos do grupo Criando - PUC: "História social da criança e da família" (ARIÈS, 1981), "História das Crianças no Brasil" (DEL PRIORE, 2010), "O Desaparecimento da Infância" (POSTMAN, 1999) e "Corpo Infância - Exercícios tensos de ser criança: por outras pedagogias do corpo" (ARROYO, 2012) e a mais recente obra: "A cruel pedagogia do vírus" (SANTOS, 2020). (p. 18).

Assim, este manifesto possibilita a compreensão do encadeamento, que se apresenta neste período de pandemia, sob as diferentes e congruentes perspectivas, sobretudo concernentes ao cenário a que estão sujeitos os bebês e crianças. Busca estabelecer uma relação entre o que é materializado e o que está prescrito nos textos legais.

Nesse diapasão, as autoras, de maneira poética, musical e dialógica, iniciam cada seção do livro com excertos que introduzem a temática, aguçando o leitor a prosseguir na leitura. Elas se esmeram em contemplar, de forma panorâmica, diferentes possibilidades de reflexão sobre a educação na infância em tempos de pandemia, que representam cada seção do livro: Infâncias: direitos e contextos; A discussão da pandemia no cenário sociopolítico; Crianças: sujeitos de direitos em qualquer tempo; A escola da infância e as culturas infantis; A criança como sujeito social que constrói a sua história; Relatos de infância e o olhar do professor; Mídias na infância: aproximações e distanciamentos; A escola na pandemia como espaço para o acolhimento e a História continua. (n.p.).

Dessa maneira, as questões da diversidade de territórios, de constituição familiar, das condições sociais e do ritmo de desenvolvimento são pontualmente asseveradas pelas autoras, que afirmam que devem ser contempladas ao se tratar deste assunto que nos é tão caro, a infância, tendo em vista que não é igualitária e a diversidade "é o que caracteriza a natureza humana". Dessa forma, é inaceitável pensar a criança como “vir a ser”. (p. 25). Ela já é e precisa ser respeitada em sua diversidade e suas especificidades devem ser consideradas.

O manifesto ecoa frente aos silêncios que se instalam em meio as vulnerabilidades a que muitas crianças e suas famílias ficaram (estão) expostas: dificuldade de higiene pessoal e limpeza de seus espaços, de distanciamento social, de oferta de alimentação, de moradia e de óbitos de entes queridos. Nessa esteira de entendimento, as autoras buscam refletir sobre "como possibilitar que todas as crianças tenham assegurado o direito de serem ouvidas e acolhidas em suas necessidades, incluindo as crianças cujas infâncias encontram-se ainda mais precarizadas". (p. 28). 
As autoras denunciam a naturalização e a banalização da quantidade de pessoas que perderam suas vidas, frente às justificativas neoliberais de que o número de mortes é ínfimo em relação à destruição da economia do país. Há que se fazer algo frente à Necropolítica velada.

Outra questão instigadora, que as autoras apontam, em contraponto à opinião excludente de muitos, é a alimentação como ato pedagógico, afirmando que as políticas públicas de alimentação escolar estão em passo avançado para a transposição de caráter assistencialista de merenda aos estudantes vulneráveis, para a concepção de alimentação adequada para todos, como fruto da garantia de direitos. São imperativas em dizer que, enquanto não há possibilidade de encontros presenciais, sejam garantidos aos pequenos comida, segurança, diversão e arte, parafraseando a banda Titãs.

Outrossim, a questão da educação infantil, pensada pelo viés adultocêntrico, é outro ponto manifesto nessa obra. É preciso romper com as relações de dominação e passar a considerar, também, a perspectiva do bebê e da criança como protagonistas, autores de pensamentos e produtores de culturas infantis, em distintas possibilidades de inter-relações. A legislação deve ter consonância entre as letras e a ação pedagógica, e nessa perspectiva, é essencial pensar na formação continuada do docente.

O livro traz algumas reflexões sobre a imersão dos bebês e crianças aos aparatos tecnológicos, que foram aguçados em tempos de pandemia e de atendimento com propostas pedagógicas remotas, devido à necessidade de distanciamento social. As autoras apresentam proposições para a recondução do percurso didático, considerando a indissociabilidade do cuidar e do educar e ofertando interações significativas para a infância, sem artificialização e nem interações desconexas. As propostas versam sobre três vertentes importantes: "qualidade do tempo está relacionada com a construção de vínculos virtuais, equilíbrio das experiências e linguagens e políticas públicas intersetoriais". (p. 64, 66 e 67).

Essas são algumas temáticas delineadas nessa sucinta, mas profunda, obra. Refere-se à uma leitura provocativa, que leva o(a) leitor(a) a viajar por suas páginas e temas tratados de maneira fluida, abrindo leques de possibilidades, como fagulhas libertadoras para pensar sobre a superação da barbárie, que ainda está tão presente em nossa sociedade, sobretudo nas relações educacionais. O diálogo e a escuta ativa são imprescindíveis, contudo não na perspectiva de dar voz ao outro, como se aquele fosse detentor do poder e exercesse um ato de generosidade, mas na perspectiva de construção colaborativa e respeitosa.

As autoras, em suas reflexões, apontam alguns caminhos para ampliar o debate: é urgente a convergência de políticas públicas com enfoque mais aguçado ao bebê e à criança com maiores necessidades, de forma equitativa. Objetivo maior: Educação de qualidade, que 
garanta o acesso e permanência com qualidade, que leve em conta as diferenças, a cultura local e a democracia efetiva no âmbito educacional, em prol da justiça social.

Com maestria, as autoras conduziram este manifesto e, ao final, apresentam um apelo aos educadores e às educadoras, para que não se calem e sejam as vozes representativas das crianças (sem silenciá-las), que precisam da ajuda daqueles(as) que são ligados(as) à educação da infância, inspirados(as) pela amorosidade freireana e junto às crianças. O livro indica que a reflexão não se finda nessa produção e a história continua a ser tecida.

\section{Referência}

SANCHES, Emília Cipriano. (Org); TOQUETÃO, Sandra Cavaletti. (Org.); MONTEIRO, Shirlei Nadaluti. (Org.). Uma janela de possibilidades na educação da infância em tempos de pandemia. 1. ed. Campinas, SP: Pontes Editores, 2020. 